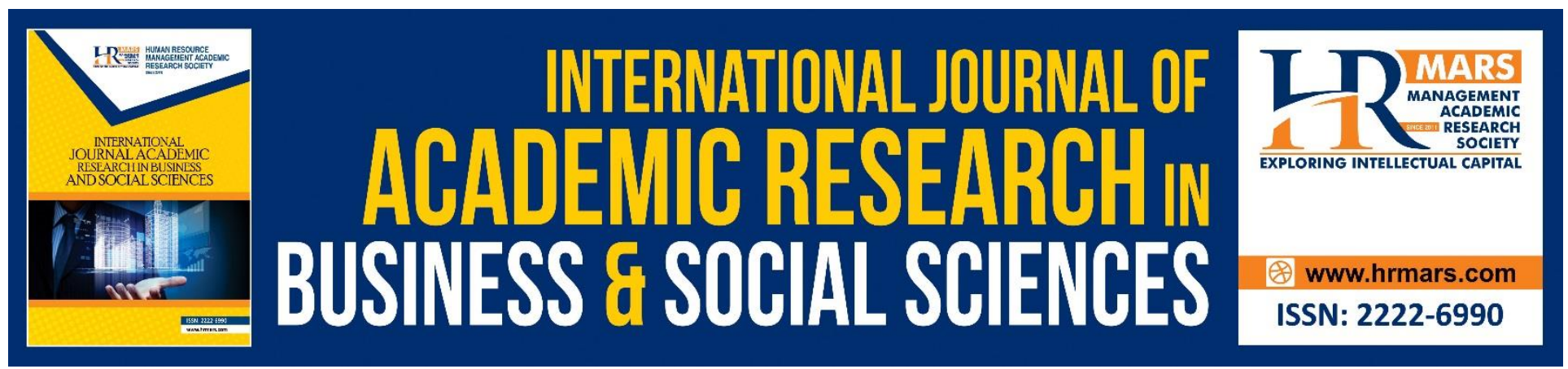

\title{
The Concept of Halalan Tayyiba in Food According to Mufassir
}

Nor Sakinah Mohamad, Wan Mohd Khairul Firdaus Wan Khairuldin

To Link this Article: http://dx.doi.org/10.6007/IJARBSS/v8-i11/4967

DOI: $10.6007 /$ IJARBSS/v8-i11/4967

Received: 19 Sept 2018, Revised: 21 Oct 2018, Accepted: 06 Nov 2018

Published Online: 08 Nov 2018

In-Text Citation: (Mohamad \& Khairuldin, 2018)

To Cite this Article: Mohamad, N. S., \& Khairuldin, W. M. K. F. W. (2018). The Concept of Halalan Tayyiba in Food According to Mufassir. International Journal of Academic Research in Business and Social Sciences, 8(11), 902-909.

Copyright: (C) 2018 The Author(s)

Published by Human Resource Management Academic Research Society (www.hrmars.com)

This article is published under the Creative Commons Attribution (CC BY 4.0) license. Anyone may reproduce, distribute, translate and create derivative works of this article (for both commercial and non-commercial purposes), subject to full attribution to the original publication and authors. The full terms of this license may be seen

at: http://creativecommons.org/licences/by/4.0/legalcode

Vol. 8, No. 11, 2018, Pg. 902 - 909

http://hrmars.com/index.php/pages/detail/IJARBSS

JOURNAL HOMEPAGE

Full Terms \& Conditions of access and use can be found at http://hrmars.com/index.php/pages/detail/publication-ethics 


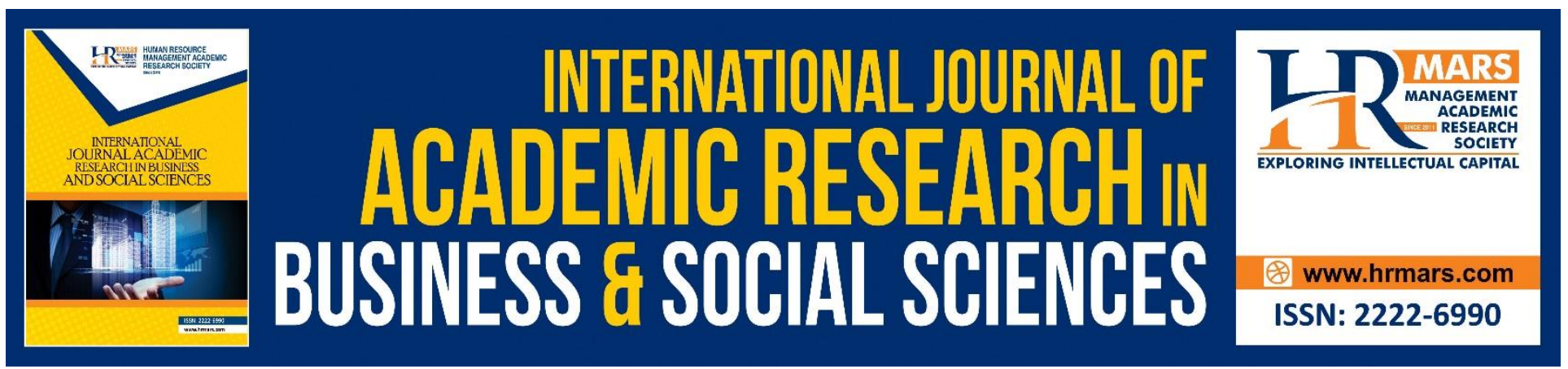

\title{
The Concept of Halalan Tayyiba in Food According to Mufassir
}

\author{
Nor Sakinah Mohamad, Wan Mohd Khairul Firdaus Wan Khairuldin \\ Faculty of Islamic Contemporary Studies, Universiti Sultan Zainal Abidin, \\ Terengganu. Malaysia \\ Email : wanfirdaus@unisza.edu.my
}

\begin{abstract}
This paper discusses the Concept of Halalan Tayyiba In Food According to Mufassir in the selected interpretation book. The Halalan tayyiba is a very important concept in today's life, especially the halalan tayyiba that are related to the food that is the daily necessity of man. The question is how the views of the mufassir relate to the concept of halalan tayyiba in food. This paper aims to identify halalan tayyiba concepts. Furthermore, this paper also aims to analyze the views of mufassir based on the interpretation of the Qur'an on the concept of taiyyiba elections. The method of data collection using the documentation method involves our books of interpretation selected for the dissemination of data analysis. The preliminary findings show that the concept of taiyyiba elections is important to ensure that the food they take is beneficial to humans.
\end{abstract}

Keywords: Halalan Tayyiba, Food, Mufassir

\section{INTRODUCTION}

Allah s.w.t creates his creatures with various advantages and disadvantages. Allah s.w.t with his generous and compassionate nature has provided all the necessities needed by man in this world, from small things to greatness. Allah s.w.t has set rules and concepts for his servants to take guidance in order to continue their life in this world. One of the rules and concepts set by him is the concept of Halalan Tayyiba in food, especially to his Muslim servants. Muslims are encouraged to take halal, clean and safe food (Zulaekah \& Kusumawati, 2005). In Islam there is a concept related to food which is the concept of taiyyiba (good). This is based on the word of Allah s.w.t in surah al-Baqarah, verse 168:

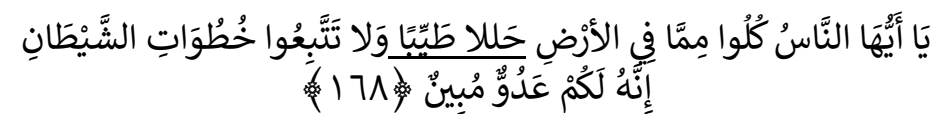

O mankind, eat from whatever is on earth [that is] lawful and good and do not follow the footsteps of Satan. Indeed, he is to you a clear enemy. 
(Surah al-Baqarah, 2:168).

Islam is a very systematic religion that has its guide from all things. In the chapter of food, Islam gives very much attention to the halal of a food that is taken by humanity even more on the food of Muslims. A good Muslim will pay attention and take care of food and drink, so that their food is halal, good and obey the syarak. (Wahab \& Azhar, 2014). Islam strongly emphasizes good nutrition for the body, because Islam is very concerned from the beginning of the food preparation process, the source of food is obtained, as well as the cleanliness of the place of cooking as well as the way the cooking is taken care. (Mohd Hamim Rajikin, Baharudin Omar \& Suhana Sulaima, 1997).

\section{METHODOLOGY}

This study uses design methods to get a clear picture of The Concept of Halalan Tayyiba in Food According to Mufassir. This method is a procedure for processing and collecting data based on systematic planning involving a set of related variables. Regular arrangement of proposals will get the research design. To obtain information related to the concept of Halalan Tayyiba, this paper chooses selected books of tafsir, classical and contemporary fiqh works which there were debates about this concept which is then collected and examined. This method is in line with this second study method, which is the method of collecting data.

Furthermore, the result of the data collection method will be analyzed using the content analysis method. The content analysis will be used extensively against the data obtained in this paper to summarize and explain what is contained in the concept of halalan tayyiba in this paper work. Qualitative research is a method of analyzing the content used to analyze things. (Neuendorf, 2002). Documented data will get good results through content analysis. (Yusof, 2004). According to (Lebar, 2009), the analysis of this content will also explain some of the explicit content contained in the text. This is in line with the data collected from the documents related to this taiyyiba election concept.

\section{FINDINGS}

This study divides the discussion into three things. First, the discussion on the concept of nutrition in Islam. The second discussion is about the concept of halalan tayyiba. As well as the third discussion is the views of mufassir on the concept of halalan tayyiba.

\section{CONCEPT OF FOOD IN ISLAM}

Food is something that everyone needs, regardless of who is Muslim or who is non-Muslim. Food is an essential ingredient, of which the good of the food will produce the energy needed by all humans. The energy is used to carry out all activities in life. The originally law for the food is permitted (mubah). so there is one nas or the dalil in the Qur'an and the hadith, nor the study that says the food is haram and harasses humans. In the fiqhiyyah method there are several methods, one of which is the fiqh method:

Al-asl fi al-asya' al-ibahah (الأصل في الأشياء الإبحة) which means everything that Allah has given is necessary until there's dalil came to pass (Ahmad, 2002). 
The food is the grace and favor Allah has given to his servant, as a sign of love and affection for the creator of his creatures. Allah s.w.t has governed mankind in terms of food that God commanded man to search and eat food that is lawful (Hadi Rohadi Abdul Fatah, 2010). Food is halal as long as it benefits humans. When there is doubt in a food whether it is halal or haram, and there is no sign in it, it is best to keep away from it.

There are several causes that cause food to be haram, among them is that the food is harmful whether harmful to yourself and others. Eating beyond the boundary is also included in the dangerous category. Among other causes, the food is intoxicating and damaging to human reason and mind. As Hadith from the Prophet's wife s.a.w, he said that the Prophet s.a.w said:

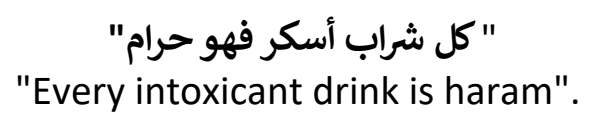

(Riwayat Muslim, no hadith 2001)

Other than that the food is in it. The food is also not his own where the food belongs to others. Whether the food is loot or stolen. So the food is illegal to humans.

Foods that are haram according to the Islamic law of Shari'ah are the carcasses, the dead carcasses, the fallen and dead animals, the animals that are hit by hard objects then die and many more except for seafood, this is because the carcasses of the oceans are halal. The flowing blood is also included in what is banned in Islamic law of Shari'ah. Among them are animals slaughtered by the name of Allah s.w.t. Allah has said that, "and do not eat the animals which Allah does not mention when he slaughtered them, indeed the act was a rebellious thing. Animals with fangs, rooted birds, that are birds of prey are illegal to eat by Muslims. Animals slaughtered for other than Allah s.w.t are also illegal to eat them. Like animals slaughtered for idolatry, for the sea and so wicked, then it is illegal (Irfan, n.d.).

\section{THE CONCEPT OF HALALAN TAYYIBA}

Allah s.w.t with his generous and loving nature has created creatures in this world by having its own advantages and disadvantages. Allah swt created human beings, to complement this human creation's grace and Allah has assigned a guideline and rule to mankind, these rules and guidelines encompass all things including in the food chapters, where this food is a very important requirement for man to gain energy. In granting this food supply, Allah s.w.t has set up Halalan Tayyiba concept, which is a halal food good for the body, for the sake of doing daily activities and energy to worship it. Halal is a word contained in the Qur'an, the election is created from the word halla, yahillu and hillan which means to liberate, release and allow something. This halal is used in many respects and has a different role, one of which is halal in relation to food and beverages (Ali, 2016). Halal also carries a broad sense of meaning, which is synonymous with the practice of living Muslims who practice the aspects of the taiyyiba election.

Halal is the opposite of Haram. Halal means pure purity and can be used, whereas haram is something that leads to harm, damage and cannot be used and has no benefit and goodness from it. According to Rahman (2007), there are guidelines that enable us to define food taiyyiba, as follows:

a) The food is not found on any part or things which is prohibited and banned by Allah s.w.t. 
b) There is nothing in it that is categorized as unclean according to syarak.

c) The food is not provided and processed by the tools and objects that the law is categorized as unclean.

From the previous statement, it can be concluded that the concept of this halalan tayyiba is a concept of halal is good, which is a duty to man, especially the servant of Allah s.w.t who is a Muslim to practice it. Searching for the lawful is the duty of all same as abandoning and keeping away from the haram. Which is a matter of harm to many people. The things that haram is for the benefit of human beings and this can be excluded when there is a condition that requires eating illegal food.

The concept of this halalan tayyiba, not just to look at the result of the food alone. Even this halalan tayyiba concept covers everything. From the beginning of the production and processing of the food. Whether from the field, the plant, the machine and the place where it is built. Everything is taken into account in this concept. This is because in order to keep the food from beginning to end (Rajikin, Omar \& Sulaiman, 1997).

\section{MUFASSIR'S VIEW OF TAIYYIBA ELECTION}

Allah s.w.t mentioned in the Qur'an and clearly state this concept in surah al-Baqarah verse 168 regarding the concept of this halalan tayyiba. Allah s.w.t said:

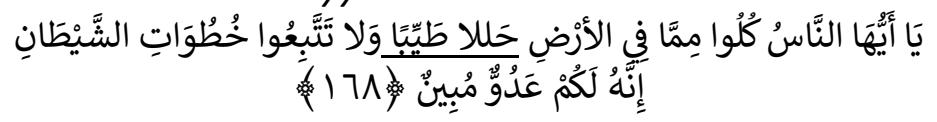

O mankind, eat from whatever is on earth [that is] lawful and good and do not follow the footsteps of Satan. Indeed, he is to you a clear enemy.

To understand something that God has said, interpretation is needed to better understand what is meant and the purpose of the verse is revealed. So to understand the view of the mufassir is needed. Revolving around the concept of taiyyiba elections these five interpretations will be used to translate them. The books are the Tafsir of Ibn Kathir, the Tafsir of Al-Qurtubi, the tafsir of al-Sa'di, the Tafsir al-Quran al-Aisar and Tafsir of al-Azhar.

According to IbnKathir (2000), Allah s.w.t has explained that he was the one who created man and gave his servant a sustenance, no one worthy of worship except Allah s.w.t. with his powerful and authoritative nature, Allah s.w.t has given his servants the provision, and gives people the permission to eat everything in the world as long as the food is halal and good. The good means that gives good and does not endanger life when the food is taken. Everything that Allah created for his slave is halal, and Allah s.w.t creates a tendency to goodness.

In the commentary of al-Qurtubi (2006), it says that the verse was revealed to the tribes of Tsaqaf, the tribe of Khuza'ah and the Bani Mudlij tribe. This is because they have been doing what forbidden by Allah s.w.t. However, according to Imam Qurtubi this verse is a common verse. That is not just about the food that only haram, but also other foods. According to him, halal is to liberate and escape from something that prohibits and hinders from eating it. Halal and good food is what gives people the desire to eat it. There is also food that cannot take benefits from it, which is a disgusting and dirty food, which does not attract people to eat it. 
INTERNATIONAL JOURNAL OF ACADEMIC RESEARCH IN BUSINESS AND SOCIAL SCIENCES Vol. 8, No. 11, Nov, 2018, E-ISSN: 2222-6990 @ 2018 HRMARS

According to Al-Sa'di (2007), Allah s.w.t has given the gift to all mankind, regardless of which Muslims or non-Muslim, and that purity is food. Allah s.w.t has ordered to eat everything on earth from the crops, fruits and animals that are in the state of halal. What is meant by halal is what Allah s.w.t allows man to eat. Not food from stolen products, loots or in any circumstances that leads to banned. The food is not just halal but must be good, that is not dirty food such as carcasses, pigs, and anything else that dirty. This verse also explains that the origin of everything that Allah s.w.t is good for eaten and used. And that haram is from two situations which are from the food itself, and the food which is forbidden because it is related to the rights of Allah and the human rights.

HAMKA (1981), said, Allah has called upon all creatures to organize food. The food meant here is halal and good food. Halal food is the opposite of illegal food, which is the food that Allah has revealed to us in the Qur'an as pigs, blood and what is slaughtered not mentioned in Allah's name and slaughtered for idols. The food must be good and not just halal. The meat slaughtered must be cooked before eaten it while still raw. There is therefore a good consideration from man and not beyond bounds. The food must also be found in a good way, and not in the way of hijacking other people, being taken in the way of deceit, stealing and others. Halal and good food affects human spirit.

According to al-Jazairi (2010), the meaning of Al-Halal is all that is safe from something dangerous, all that is allowed by Allah to take benefits from it. While al-Thayyib means something good, pure, and non-unclean. Allah has called upon man to eat and enjoy all that is halal of his giving on this earth. So all that is banned from taking it has a bad effects and harmful to the body and the human soul itself.

Table 1: Summary of literary texts

\begin{tabular}{|l|l|l|}
\hline BIL & \multicolumn{1}{|c|}{ BOOK NAMES } & \multicolumn{1}{c|}{ CONTENTS } \\
\hline 1. & Tafsir of Ibn Kathir & $\begin{array}{l}\text { Halalan Tayyiba is the food endowed by } \\
\text { Allah s.w.t, all the food endowed by Allah is } \\
\text { halal unless there is a nas that causes it to } \\
\text { be haram. The food also provides good and } \\
\text { safe for the soul and body. }\end{array}$ \\
\hline 2. & Tafsir of al-Qurthubi & $\begin{array}{l}\text { Islam demands muslims to take food that is } \\
\text { halalan tayyiba even from the beginning of } \\
\text { its production. }\end{array}$ \\
\hline 3. & Tafsir of al-Sa'di & $\begin{array}{l}\text { Halalan tayyiba is the food endowed by } \\
\text { Allah s.w.t which is found in a good way. }\end{array}$ \\
\hline 5. & Tafsir of al-Aisar & \begin{tabular}{l} 
Halalan $\begin{array}{l}\text { tayyiba is a well-found and } \\
\text { excessive food. Halal food must be in good } \\
\text { condition. }\end{array}$ \\
\hline Halalan tayyiba is everything that is safe and \\
does not contain any defective material. \\
Everything that is haram has a bad effect on \\
the body.
\end{tabular} \\
\hline
\end{tabular}




\section{DISCUSSION}

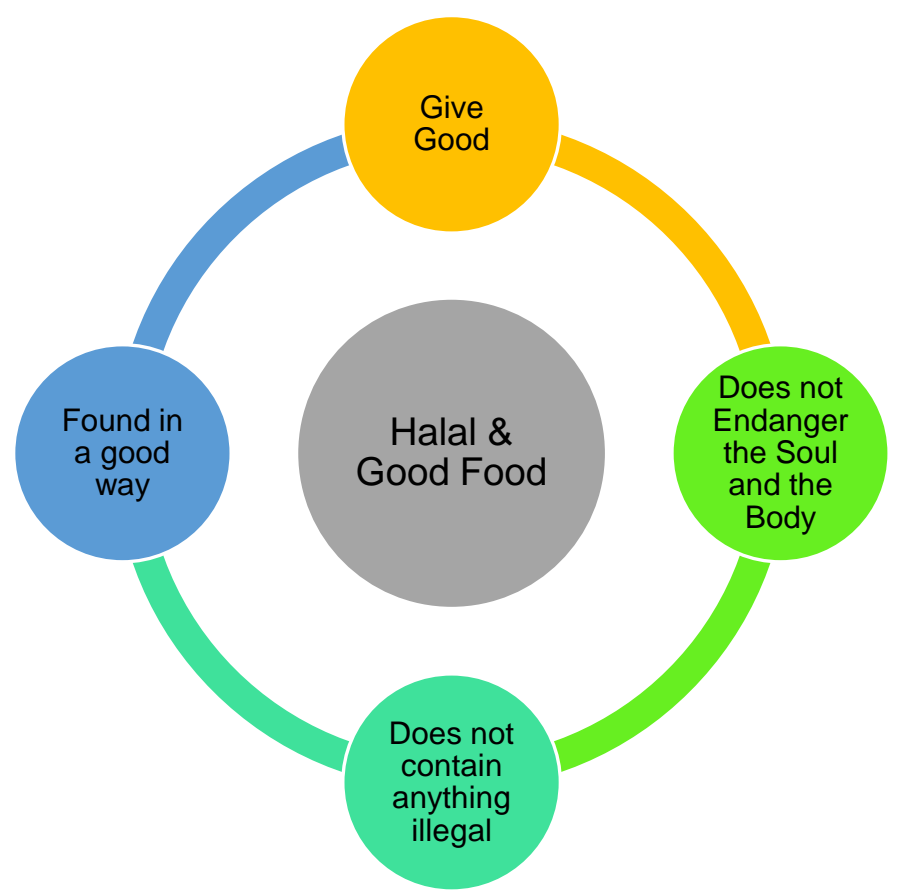

Figure 1: Halal and Good Food

Halal and good food is very much needed by humans. This halal food is a food that does not harm the soul and the body of the human being. There is also nothing in it that Allah s.w.t. has forbidden such as animal meat that is haram, carcasses, blood and so forth. Haram food is to safeguard the safety of those who eat it. Illegal food has a bad effect that causes Allah s.w.t to forbid man from eat it. This halal and good food also provides good and nutritious which will produce energy for the human body. In addition, the issue of halal should be taken into consideration from the beginning of the food processing itself.

According to the selected mufassir, they all agree that halal food is a gift from Allah s.w.t to his servant and it is halal and good from the beginning. Like Ibn Kathir said that the halal food that benefits the soul and the human body is more common. Al-Qurthubi also sees from the start of good food itself, until the end of the food productions. According to al-Azhar, the halal food must not be excessive and in good condition. In the Tafsir of al-Aisar, it is said that the halal food must not contain any foul and what is harmful.

\section{CONCLUSION}

The concept of halalan tayyiba is a very important concept to be understood. This is because food is a substance which then produces the energy needed by humans. According to mufassir experts all say that the halal and good food comes from Allah s.w.t which is endowed upon all his servants. The food that is taken must be good, which gives good to the person who takes it. All of the food that Allah s.w.t has against is illegal. Illegal food is anything that harms the body. How to get the food should also be in a good way. It is not by stealing, forcing and loots the rights of others. Although the food is halal, but if the way to get it is not good, it cannot be eaten. 
INTERNATIONAL JOURNAL OF ACADEMIC RESEARCH IN BUSINESS AND SOCIAL SCIENCES Vol. 8, No. 11, Nov, 2018, E-ISSN: 2222-6990 @ 2018 HRMARS

In conclusion, based on all that has been discussed in the paper and what has been described above can be drawn to the result that Allah s.w.t has given the provision (rizq) for mankind with abundance, which is halal and good as contained in the Quran and hadith. It is obligatory for people especially those who are Muslims to look for halal and good for the soul and body. Halalan tayyiba must be taken into account from the beginning of its production, how to get it and where the food is produced until the process to take advantage of it.

\section{ACKNOWLEDGEMENT}

This project was funded by the Special Research Grant Scheme (SRGS) from UniSZA (UniSZA/2017/SRGS/07). We would like to thank UniSZA for the financing provided.

\section{REFERENCES}

Muslim, I. H. (1991), Sahih Muslim. Beirut: Dar Al-Kitab Al-Alamiyyah

Al-Qurtubi, M.A. (2006), Al-Jami'lil Ahkam Al-Qurtubi, Beirut :Mua'asasah Al-Risalah.

Al-Jazairi, A.B. (2010). Tafsir Al-Quran Al-Aisar, Jakarta: Terbitan Darus Sunnah.

Rahman, A.A. (2007). Panduan Penentuan Makanan Halal Menurut Pandangan Ulama Serta Kesannya Terhadap IKS Muslim Di Malaysia. Convention of Islamic Entrepreneurships 2007 (iCEPS 2007). 20-21st January 2007. Dewan Kuliah Pusat 1 KUIM.

HAMKA.(1981). Tafsir Al-Azhar. Surabaya: Yayasan Latimajong.

Wahab, H.A. \& Azhar, A. (2014). Halalan Tayyiban Dalam Kerangka Perundangan Malaysia, Jurnal Undang-Undang Malaysia, 26(1).

Fatah, H.R.A. (2010). Pedoman Dan Tata Cara Pemotongan Hewan Secara Halal. Indonesia. Jakarta: Kementerian Agama RI.

IbnKathir, I.. (2000) Tafsir Ibn Kathir. Riyadh: Dar al-Salam.

Rajikin, M.H., Omar, B. \& Sulaiman, S. (1997). Pemakanan Dan Kesihatan. Kuala Lumpur: Dewan Bahasa Dan Pustaka.

Ali, M. (2016). Konsep Makanan Halal Dalam Tinjauan Syariah Dan Tanggungjawab Produk Atas Produsen Industri Halal, Kementerian Agama Republik Indonesia.

Ahmad, M.S. (2002). Usul Fiqh dan Qawaid Fiqhiyyah. Pustaka Haji Abdul Majid, Kuala Lumpur Man, S \& Yahaya, Z.A.. (2014). Halalkah Makanan Kita?. Batu Caves: PTS Islamika Sdn.Bhd.

Zulaekah, S. \& Kusumawati, Y. (2005). Halal Dan Haram Makanan Dalam Islam. Fakultas IImu Kedokteran Universitas Muhammadiyah Surakarta.

Khairuldin, W.M.K.F.W. (2010), Metode Fatwa Sheikh 'Ali Jumaa'ah dalam Kitab al-Kalim al-TayyibFatawa 'Asriyyah. Unpublished Master Thesis. University of Malaya.

Khairuldin, W.M.K.F.W. (2016), Konsep Fatwa dalam Islam. Kuala Terengganu: Penerbit Universiti Sultan Zainal Abidin.

Khairuldin, W. M. K. F. W., Embong, A. H., Anas, W.N.I.W.N., Mohd, H. \& Ismail, D. (2018). The Application of Technology in the Dissemination of Fatwas: A Study on Religious Institutions in Malaysia, International Journal of Civil Engineering and Technology, 9(7), 2018, pp. 15901596.

Al-Sa'di, A.R. (2007). Tafsir As-sa'di, Jilid 1, Penerbit, Pustaka Sahifa, Jakarta Indonesia. 